\title{
Lethal Co-infection of Rotavirus and E. coli O157:H7 in Mediterranean Buffalo Calves
}

\author{
L. De Martino, F. Fiorito, G. Pisanelli, S. Nizza, K. Mallardo, R. Schettini, S. Montagnaro, G. Iovane and U. \\ Pagnini \\ Department of Pathology and Animal Health, Section of Infectious Diseases, School of Veterinary Medicine, University of Naples \\ “Federico II”, Naples 80137, Italy
}

Received: April 6, 2011 / Published: November 20, 2011.

\begin{abstract}
In this paper, we reported lethal episodes in buffalo calves, due to rotavirus and concurrent infection with E. coli O157:H7, in a closed community in Italy. A first detection of group A rotavirus infection was made by using an immunochromatographic assay, the virus isolation was performed on Monkey kidney cells (MA-104), and the rotavirus isolates were G and P characterized by a reverse transcription (RT)-PCR assay using a nested multiplex method. Co-infection with E. coli strains was demonstrated by classical bacteriological procedures. The E. coli isolates were analysed by Vero cell assay and PCR. This study showed the presence of group A rotavirus of G6-P5 serotypes and verocytotoxin producing or non-producing E. coli O157:H7 in faecal samples. So far the concomitant presence of rotavirus and E. coli O157:H7 in cases of enteritis in Bubalus bubalis in Italy is not reported in the literature, as well as the mortality of buffalo calves probably due at an additional virulence factor, Shiga toxin 1 (st $x 1$ ) gene, of the E. coli O157:H7 strains.
\end{abstract}

Key words: Rotavirus, E. coli O157:H7, buffalo calf, diarrhoea, Italy.

\section{Introduction}

The Mediterranean buffalo (Bubalus bubalis) represents a separate genus within the family of Bovidae and enteritis attributed to virus or/and bacteria in this species has not been much investigated. Interest in buffalo farming is growing in Italy, and particularly in South where is about $80 \%$ of the national buffalo assets are present [1].

Neonatal diarrhoea, or buffalo-calf scours, continues to pose a major health and economic threat for the buffalo-breeding. Affected buffalo-calves develop severe diarrhoea, leading to dehydration, electrolyte imbalance, and acidosis. Death, impaired performance, retarded growth, and the added time and expense of treating sick animals all contribute to economic loss.

Corresponding author: U. Pagnini, professor, DVM, research fields: veterinary infectious diseases, veterinary immunology. E-mail: upagnini@unina.it.
Infectious causes of buffalo-calf scours include enteric strains of rotavirus and coronavirus, Escherichia coli, salmonellae, strains of clostridia, and coccidia and cryptosporidia. Noninfectious causes include environmental conditions (wet, drafty quarters, dirty pens, stress) and nutritional factors (over-feeding, poor quality milk replacer) [2].

Rotavirus is the major etiologic agents of severe, acute dehydrating diarrhoea in many mammalian species, including man, calves, buffalo and pigs. The rotaviruses (Reoviridae family) are characterized by the presence of 11 segments of double-stranded RNA (dsRNA) enclosed in a triple-shelled protein capsid. The outer capsid of the rotavirus is made up of two structural proteins, VP7 and VP4, which elicit neutralizing antibodies. VP7, which is a glycoprotein and hence designated $G$, is the major neutralization antigen of the virion and defines its G serotype. VP4, designated $\mathrm{P}$, is a protease-sensitive protein, and 
infectivity is activated by the cleavage of this protein. Both $\mathrm{G}$ and $\mathrm{P}$ form the basis of rotavirus classification and description [3]. On the basis of sequence and antigenic differences, $15 \mathrm{G}$ types and $21 \mathrm{P}$ types have been described $[4,5]$.

Knowledge of the diversity and distribution of $G$ and $\mathrm{P}$ types circulating in a community is crucial to the formulation of an adequate vaccine as well as the evaluation of protection after vaccination. Furthermore the significant number of animal reservoirs in combination with the various strains of rotaviruses provides the possibility for dramatic genetic shifts in the virus. This drastically increases the microbial virulence of the disease.

The new-born buffaloes present diarrhoea mainly over the first four weeks of age. Ram Mohan et al. [6] and El-Ghari et al. [7], in India and Egypt, also observed the highest occurrence of diarrhoea during this period. Among bacterial pathogens, E. coli is the most prevalent agent observed in diarrhoeic calves, and often is isolated alone. Cattle, especially young animals, have been implicated as a principal reservoir of enterohemorrhagic E. coli (EHEC) serotypes and the well-publicized outbreaks of infection with E. coli O157:H7 [8]. E. coli O157:H7 is an emerging cause of foodborne illness. It is known that most strains of $E$. coli are harmless and live in the intestines of healthy humans and animals. However, E. coli O157:H7 produces a powerful toxin and can cause severe illness, and it is well-known that complications can be very serious, even deadly.

Little is known about the association of E. coli O157 with the diseases in naturally infected calves and of the characteristics of isolates. In a recent past, experimental infections have demonstrated that the organism is not pathogenic in older calves and adults $[9,10]$. More recently the occurrence of E. coli O157 in young calves associated with/without diarrhoea has been investigated and no significant difference was found in the occurrence rates between these diarrhoeic and non-diarrhoeic calves [8].
In the present study we described the detection of rotavirus and concurrent infection with enterohemorrhagic E. coli $\mathrm{O} 157: \mathrm{H} 7$ in eight young buffalo-calves diarroheic faecal specimens of a field outbreak in southern Italy. Furthermore, the death of four animals of this studied group seemed to be related to strains of verocytotoxin-producing E. coli O157:H7. The data presented herein adds to the current knowledge on the buffalo calf diarrhoea causes, and we retain this result very important also for the major potential risk factors to which the rural population is exposed.

\section{Materials and Methods}

\subsection{Specimen Collection}

Diarrhoeic faecal samples from young buffalo-calves, of about 30 days old, from a farm located in the province of Caserta (South Italy), were used in this study. All animals showed similar clinical symptoms and history of diarrhoea, and never had been vaccinated against rotavirus or E. coli infection. Other animals (small or large ruminants) were not present in the buffalo herd examined.

\subsection{Rotavirus Isolates}

A first detection of group A rotavirus was made by using an immunochromatographic assay (Rotascreen Dipstick M580 Microgen Bioproducts, Camberley, UK) according to the manufacturer's instructions. Monkey kidney cells, MA-104, were used for virus isolation. The cells were grown in Dulbecco's minimal essential medium (D-MEM), supplied with $10 \%$ foetal calf serum. The isolates rotavirus strains obtained from the faeces of the animals affected by severe diarrhoea were characterized. Specimens were collected directly from the rectum ampulla, diluted 1:5 in phosphate-buffered saline (PBS) and homogenized. The resulting faecal suspension were centrifuged at $4{ }^{\circ} \mathrm{C}$ for $30 \mathrm{~min}$ at $3,000 \mathrm{~g}$ and the supernatants diluted $1: 2$ in D-MEM containing $1,000 \mu \mathrm{g} / \mathrm{mL}$ of trypsin and filtered by $0.22 \mu \mathrm{m}$ filters (Millipore, 
Bedford, MA). Each sample was inoculated onto the MA-104 cell monolayer. After 60 min adsorption at $37^{\circ} \mathrm{C}$, the cells were supplied with D-MEM enriched with $1 \%(\mathrm{v} / \mathrm{v})$ of foetal calf serum and $5 \mu \mathrm{g} / \mathrm{mL}$ of trypsin. In the presence of cytopathic effect (CPE), an indirect immunofluorescence test (IFI) was carried out on the infected cells using rabbit hyperimmune serum to rotavirus.

\subsection{Reverse Transcription-Polymerase Chain Reaction (RT-PCR) Genotyping}

The genomic dsRNA of each isolate was extracted from the infected cell lines showing 50\% CPE, using the Trizol reagent (Invitrogen-Life Technologies, Milan, Italy) according to the technique described by the manufacturer. RNA suspensions were stored at $-20{ }^{\circ} \mathrm{C}$ until tested. The reverse-transcription followed by polymerase chain reaction (PCR) for $\mathrm{G}$ and $\mathrm{P}$ rotavirus genotyping was performed in two steps, as described by Gouvea et al. [11-13] and Gentsch et al. [14] respectively. All the RT-PCRs were performed with viral RNA extracted from reference sample as the positive control and water as the negative control. Four separate rooms, for RNA extraction, first amplification, second amplification, and gel analysis, were used to avoid cross-contamination of samples.

For the first amplification, a mixture of primers Beg9/End9 (G-genotype) and Con2/Con3 (P-genotype) was used. To asses both $\mathrm{G}$ and $\mathrm{P}$ broad reactivity the mixture was cycled in a termocycler (Eppendorf) being submitted to 35 cycles of amplification at $94{ }^{\circ} \mathrm{C}$ for $1 \mathrm{~min}, 42^{\circ} \mathrm{C}$ for $2 \mathrm{~min}$, and $72{ }^{\circ} \mathrm{C}$ for $1 \mathrm{~min}$. The amplicons were then electrophoresed on a $1.5 \%$ agarose gel in Tris-Borate-EDTA buffer (TBE). The gel was stained with ethidium bromide $(0.5 \mu \mathrm{g} / \mathrm{mL})$ and cDNAs visualized and photographed with a Polaroid camera. The nested-PCR was carried out using a mixture for the G-genotypes, using as forward primer Beg9 and a pool of specific reverse primers for the G5, G6, G8, G10, and G11 genotypes; and another mixture for the P-genotypes, using as forward primer
Con2 and a pool of specific reverse primers for the $\mathrm{P}$ genotypes P6, P [7], P [1], P [5], and P [11]. The mixtures were subjected to $10 \mathrm{~min}$ of incubation at $94{ }^{\circ} \mathrm{C}$ for activation of the DNA polymerase and 25 cycles at $94{ }^{\circ} \mathrm{C}$ for $1 \mathrm{~min}, 55^{\circ} \mathrm{C}$ for $2 \mathrm{~min}$, and $72{ }^{\circ} \mathrm{C}$ for $1 \mathrm{~min}$. All amplicons were subsequently subjected to electrophoresis on $1.5 \%$ agarose in TBE buffer containing ethidium bromide $(0.5 \mu \mathrm{g} / \mathrm{mL})$.

\subsection{Bacteriological Techniques}

Faecal samples were cultured in defibrinated sheep blood-agar, MacConkey agar and tetrathionate base. The microorganisms isolated were identified on the basis of cultural, morphological and biochemical characteristics. A loopful of the stool was inoculated on air-dried Sorbitol MacConkey (SMAC, Oxoid CM 813, Basingstoke, Hants, UK) agar plates, and incubated at $37{ }^{\circ} \mathrm{C}$ for $24 \mathrm{~h}$. Colonies that were colourless to pale, flat and smooth, circular or serrated at the edge were selected for further testing as presumptive sorbitol-nonfermenting E. coli. They were subcultured on freshly prepared SMAC, and identified according to accepted techniques [15]. E. coli O157:H7 strain ATCC 43895 was used as quality control strains.

\subsection{E. coli O157 Latex Test}

A latex agglutination test for the identification of $E$. coli serogroup O157 was used (E. coli O157 latex test, Oxoid). Sorbitol MacConkey Agar was used as the primary screen. Non-sorbitol fermenting colonies were then tested with the latex reagents, to determine whether the isolate belongs to the $\mathrm{O} 157$ serogroup and therefore a potential verocytotoxin-producing strain.

\subsection{Vero Cell Assay}

The assay described by Konowalchuk et al. [16] and modified by Pai et al. [17] was employed for testing the isolates for cytotoxicity. Briefly, a single colony from a pure culture in tryptone soy broth was incubated at $37{ }^{\circ} \mathrm{C}$ for $24 \mathrm{~h}$ in a "roller drum", a 
multipurpose low-speed $(20 \mathrm{rpm})$ rolling device employed for incubating enterohaemorrhagic E. coli, extracting toxin, and purifying the supernatant by sedimentation. The culture filtrates obtained were seeded onto Vero cell cultures. Cytotoxic activity was confirmed by microscopy. E. coli EDL933 O157:H7 was included as standard positive control, while 0.05 $\mathrm{mL}$ sterile physiological saline was used as negative control.

\subsection{PCR Amplification}

E. coli $\mathrm{O} 157$ isolates were examined by polymerase chain reaction (PCR) assay to determine the presence of Shiga toxins 1 and 2 genes (stx1 and stx2) [18] and the E. coli O157:H7 hemolysin specific target gene (hlyA) [19]. Template DNA was prepared from pure culture of isolates, grown in TSB for $18 \mathrm{~h}$ at $37{ }^{\circ} \mathrm{C}$. A $1.5 \mathrm{~mL}$ aliquot of grown culture was centrifuged, and the pellet was resuspended in $0.1 \mathrm{~mL}$ of InstaMatrix (Bio-Rad, Richmond, CA, USA). The suspension was heated at $100{ }^{\circ} \mathrm{C}$ for $10 \mathrm{~min}$ and then centrifuged at $12,000 \times g$ for $5 \mathrm{~min}$. The supernatant was used for PCR template.

\section{Results}

In this study, eight field faecal samples collected from animals involved in an outbreak of neonatal buffalo calf diarrhea in a farm of the province of Caserta (South Italy) were found to be positive for group A rotaviruses by an immunochromatographic assay (Rotascreen Dipstick). By RT-PCR analysis, we confirmed the detection of rotavirus RNA in the eight specimens tested. Primers Beg9/End9 were used for RT-PCR of the full-length VP7 gene (G-genotype) (Fig. 1), and primers Con2/Con3 for VP4 (P-genotype) (Fig. 2). Further characterization of the $G$ and $P$ serotypes of the rotavirus positive samples was carried out by a nested-PCR typing assay and a common Gand P-genotype combination, G6-P [5] rotavirus strain, was identified.

The bacteriological analysis of the samples revealed

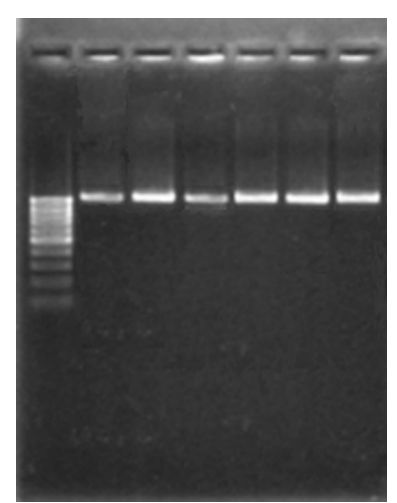

Fig. 1 A representative RT-PCR for G-genotype using Beg9/End9 primers (1,062 bp).

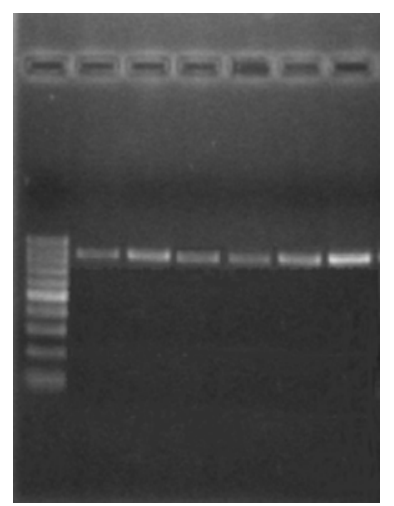

Fig. 2 A representative RT-PCR for P-genotype using Con2/Con3 primers (880 bp).

the presence of E. coli which cultured on Sorbitol MacConkey agar (Oxoid CM813) resulted to be unable to ferment sorbitol. Lack of sorbitol fermentation within 24 hours has been considered a stable phenotypic character of E. coli O157:H7. Therefore, McConkey agar containing sorbitol was used as selective media for differentiation of E. coli O157:H7 from other enteric bacteria. At the latex agglutination test for the identification of E. coli serogroup $\mathrm{O} 157$ all eight strains resulted to be positive. And, furthermore four of E. coli strains exhibited cytotoxicity in the Vero cell assay, and resulted to be positive when they were analyzed as E. coli O157:H7 by PCR for $s t x 1$ gene. The Table 1 shows the results of the PCRs for the detection of virulence genes. The health conditions of four buffalo calves, positive for sxt1-producing E. coli O157:H7 (Table 1), deteriorated gradually resulting in their death in about two weeks after the laboratory examinations. 
Table 1 Results of the PCR of the isolated $E$. coli 0157:H7.

\begin{tabular}{llll}
\hline Specimen & stx1 & stx2 & EHEC O157:H7 (hlyA) \\
\hline 1 & - & - & + \\
2 & - & - & + \\
3 & + & - & + \\
4 & + & - & + \\
5 & - & - & + \\
6 & + & - & + \\
7 & - & - & + \\
8 & + & - & + \\
\hline
\end{tabular}

- means negative result; + means positive result.

\section{Discussion}

In Italy, approximately 350,000 Mediterranean buffaloes (B. bubalis) are kept, mainly in the central and southern regions, where they constitute an important part of the animal industry in terms of milk and milk-derived products [1]. Moreover taste panel tests and tenderness measurements conducted by research teams in several countries have shown that the meat of the water buffalo is as acceptable as that of cattle. In this context, it seems necessary to know better the viral and bacteric pathogens which determine disease, both to improve the buffalo-breeding conditions and to protect the farmer's health.

In this study, we demonstrated the concomitant presence of group A rotavirus and E. coli O157:H7 in diarrhoic faecal samples of buffalo calves. The rotavirus isolates were then characterized by nested-PCR assay for G- and P-type antigens and a common G- and P-genotype combination, for the ruminants in Italy and in the world [20-23], was identified. And serotypic and genotypic characterization of rotavirus strains is important for defining the extent of diversity in circulating strains, especially prior to and after the introduction of routine vaccination. Currently, for prophylaxis of rotavirus neonatal diarrhea of large ruminants at least three vaccines are available in Italy, a killed vaccine, based on a porcine-like strain, G5-P [7], and two live modified vaccines, G6-P [1], and G6-P [5].

Several studies provide evidences that slaughtered animals like buffalo, cows and goats are reservoirs for enterohemorrhagic E. coli, including the potentially virulent strain designated E. coli O157:H7 [24]. Previous studies have documented that prevalence (ranges from $2 \%-3 \%$ to as high as $80 \%$ ), and shedding patterns of E. coli O157:H7 in the faeces of beef cattle are highly variable $[25,26]$. Isolation of verocytotoxin-producing E. coli $\mathrm{O} 157$ from $B$. bubalis in southern Italy [27], in Vietnam [28], in Bangladesh [24], in Turkey [29] has been reported.

The influence of enterohemolysin on calf intestinal disease has not been defined, but it has been suggested that enterohemolysin may complement the effects of Shiga toxins (stx) [30]. In this study, all the isolates carried Ehly gene, and four of them resulted to be positive also for stx 1 gene. This implicates that the Ehly gene, as in bovine E. coli O157 strains, also for buffalo-calves E. coli O157 strains, may be a virulence marker, and furthermore the presence of the virulence gene stx 1 increase remarkably the pathogenicity of the strain. Authors hypothesize that $E$. coli O157:H7 stx1-producing was correlated with the severe clinical signs and animal death. There is increasing evidence that haemolytic uremic syndrome and possibly hemorrhagic colitis result from the systemic action of sxt on vascular endothelial cells. Moreover the isolation of E. coli O157:H7 plus rotavirus among buffalo with diarrhoea indicates of enteric pathogens of farm health significance. The breeding situation could be also a potential source of infection for humans.

Rotavirus infection in buffalo has been reported by many authors [20, 21, 23, 31-33]. They are described as important agents causing diarrhoea in buffalo calves, either separately or in combination with E. coli ETEC, Salmonella sp., Clostridium sp. [2, 34]. But little is known of the association of enterohemorrhagic O157:H7 with disease in naturally infected calves, and particularly in naturally infected buffalo calves. 


\section{Conclusion}

This is the first report that describes the association of E. coli O157:H7 with viral disease, as rotavirus, in naturally infected buffalo-calves. Economic interest in buffalo farming is very large in South Italy, and for this reason, it will be particularly important to investigate the role of E. coli O157:H7 pathogenicity and the diffusion in neonatal buffalo calves not only in combination with rotavirus but also alone. Furthermore, this is the first study reporting evidence of stx1-producing E. coli O157:H7 and concomitant rotavirus infection in buffalo farm able to determine the death of buffalo calves.

\section{Acknowledgments}

Work is supported by grants from Italian Ministry of Health IZSM. The authors gratefully acknowledge the technical contribution of Dr. Cosimo Matrigiano and Dr. Dionea Santoro.

\section{References}

[1] National Data Bank of the Livestock Registry-Ministry of Health, CSN IZS Abruzzo and Molise, 2010, available online at: .http://statistiche.izs.it/portal/page?_pageid=73, $12918 \&$ dad=portal\&_schema=PORTAL\&op=elenco_re p\&p_report=plet_rep_bov\&p_titolo=Bovini $\% 20 \mathrm{e} \% 20 \mathrm{Bu}$ falini.

[2] D.R. Snodgrass, H.R. Terzolo, D. Sherwood, I. Campbell, J.D. Menzies, B.A. Synge, Aetiology of diarrhoea in young calves, Vet. Rec. 119 (1986) 31-34.

[3] M.K. Estes, Rotaviruses and their replication, in: B.N. Fields, D.M. Knipe, P.M. Howley (Eds.), Fields Virology, 3rd ed., Lippincott-Raven Publishers, Philadelphia, USA, 1996, pp. 1625-1655.

[4] Y. Hoshino, A.Z. Kapikian, Rotavirus serotypes: classification and importance in epidemiology, immunity, and vaccine development, J. Health Popul. Nutr. 18 (2000) 5-14.

[5] C.D. Rao, K. Gowda, B.S. Reddy, Sequence analysis of VP4 and VP7 genes of nontypeable strains identifies a new pair of outer capsid proteins representing novel $\mathrm{P}$ and $\mathrm{G}$ genotypes in bovine rotavirus, Virology 276 (2000) 104-113.

[6] S. Ram Mohan, R.S. Ram Rao, A.A. Gaffar, Studies on neonatal diarrhea in buffalo calves with special reference to epizootiology and fluid therapy, Indian Vet. J. 67
(1990) 1057-1059.

[7] M.M. El-Ghari, A.A. El-Rashidy, K.N. Mettias, E.R. Hassen, H.M. Hassen, Studies on neonatal diarrhea in buffalo calves, Proceedings of the World Buffalo Congress, São Paulo, 1994, pp. 361-363.

[8] S.J. Kang, S.J. Ryu, J.S. Chae, S.K. Eo, G.J. Woo, J.H. Lee, Occurrence and characteristics of enterohemorrhagic Escherichia coli $\mathrm{O} 157$ in calves associated with diarrhoea, Vet. Microbiol. 98 (2004) 323-328.

[9] C.A. Brown, B.G. Harmon, T. Zhao, M.P. Doyle, Experimental Escherichia coli O157:H7 carriage in calves, Appl. Environ. Microbiol. 63 (1997) 27-32.

[10] T. Ohya, H. Ito, Experimental infection of calves with Escherichia coli O157:H7, Journal of Veterinary Medicine Science 61 (1999) 1187-1189.

[11] V. Gouvea, R.I. Glass, P. Woods, K. Taniguchi, H.F. Clark, B. Forrester, et al., Polymerase chain reaction amplification and typing of rotavirus nucleic acid from stool specimens, J. Clin. Microbiol. 28 (1990) 276-282.

[12] V. Gouvea, N. Santos, M.C. Timenetsky, Identification of bovine and porcine rotavirus G types by PCR, J. Clin. Microbiol. 32 (1994) 1338-1340.

[13] V. Gouvea, N. Santos, M.C. Timenetsky, VP4 typing of bovine and porcine group A rotaviruses by PCR, J. Clin. Microbiol. 32 (1994) 1333-1337.

[14] J.R. Gentsch, R.I. Glass, P. Woods, V. Gouvea, M. Gorziglia, J. Flores, et al., Identification of group A rotavirus gene 4 types by polymerase chain reaction, J. Clin. Microbiol. 30 (1992) 1365-1373.

[15] G.I. Barrow, R.K.A. Feltham, Cowan and Steel's Manual for the Identification of Medical Bacteria, 3rd ed., Cambridge University Press, 1993, p. 331.

[16] J. Konowalchuk, J.L. Speirs, S. Starvrie, Vero response to a cytotoxin of Escherichia coli, Infect. Immun. 18 (1997) 775-779.

[17] C.H. Pai, R. Gordon, H.V. Sims, L.E. Bryan, Sporadic cases of hemorrhagic colitis associated with Escherichia coli O157:H7, Ann. Intern. Med. 101 (1984) 738-742.

[18] S.D. Bélanger, M. Boissinot, C. Ménard, F.J. Picard, M.G. Bergeron, Rapid detection of Shiga toxin-producing bacteria in feces by multiplex PCR with molecular beacons on the smart cycler, J. Clin. Microbiol. 40 (2002) 1436-1440.

[19] R.F. Wang, W.W. Cao, C.E. Cerniglia, A universal protocol for PCR detection of 13 species of foodborne pathogens in foods, J. Appl. Microbiol. 83 (1997) 727-736.

[20] V. Martella, A. Fratelli, O. Pinto, G. Ferrara, M. Tempesta, D. Buonavoglia, Typing by polymerase chain reaction of buffalo rotaviruses isolated in Italy, J. Vet. Med. 46 (1999) 499-502.

[21] A. Pratelli, V. Martella, M. Tempesta, C. Buonavoglia, Characterization by polymerase chain reaction of 
ruminant rotaviruses isolated in Italy, New Microbiol. 22 (1999) 105-109.

[22] E. Falcone, M. Tarantino, L. Di Trani, P. Cordioli, A. Lavazza, M. Tollis, Determination of bovine rotavirus G and P serotypes in Italy by PCR, J. Clin. Microbiol. 37 (1999) 3879-3882.

[23] G. Pisanelli, V. Martella, U. Pagnini, L. De Martino, E. Lorusso, G. Iovane, et al., Distribution of G (VP7) and P (VP4) genotypes in buffalo group A rotaviruses isolated in Southern Italy, Vet. Microbiol. 110 (2005) 1-6.

[24] M.A. Islam, A.S. Mondol, E. de Boer, R.R. Beumer, M.H. Zwietering, K.A. Talukder, et al., Prevalence and genetic characterization of shiga toxin-producing Escherichia coli isolates from slaughtered animals in Bangladesh, Appl. Environ. Microbiol. 74 (2008) 5414-5421.

[25] R.O. Elder, J.E. Keen, G.R. Siragusa, G.A. Barkocy-Gallagher, M. Koohmaraie, W.W. Lagreid, Correlation of enterohemorrhagic Escherichia coli O157 prevalence in feces, hides, and carcasses of beef cattle during processing, Proc. Natl. Acad. Sci. U.S.A. 97 (2000) 2999-3003.

[26] T.R. Callaway, R.O. Elder, J.E. Keen, R.C. Anderson, D.J. Nisbet, Forage feeding to reduce preharvest Escherichia coli populations in cattle, a review, J. Dairy Sci. 86 (2003) 852-860.

[27] G. Galiero, G. Conedera, D. Alfano, A. Caprioli, Isolation of verocytotoxin-producing Escherichia coli
O157 from water buffaloes (Bubalus bubalis) in southern Italy, Vet. Rec. 156 (2005) 382-383.

[28] H. Vu-Khac, N.A. Cornick, Prevalence and genetic profiles of Shiga toxin-producing Escherichia coli strains isolated from buffaloes, cattle, and goats in central Vietnam, Vet. Microbiol. 126 (2008) 356-363.

[29] E. Seker, Y. Kuyucuoğlu, B. Sareyyüpoğlu, H. Yardımcı, PCR detection of Shiga toxins, enterohaemolysin and intimin virulence genes of Escherichia coli O157:H7 strains isolated from faeces of Anatolian water buffaloes in Turkey, Zoonoses Public Health 57 (2010) 33-37.

[30] J.P. Nataro, J.B. Kaper, Diarrheagenic Escherichia coli, Clin. Microbiol. Rev. 11 (1998) 142-201.

[31] L. Muniiappa, G.K. Georgiev, D. Dimitrov, K.B. Mitov, E.H. Haralambiev, Isolation of rotavirus from buffalo calves, Vet. Rec. 120 (1987) 1-23.

[32] A. Singh, R. Pandey, Analysis of electropherotypes of rotavirus from diarrhoeic faeces of neonatal buffalo calves in India, Acta Virol. 32 (1988) 156-159.

[33] N.P. Sunil Chandra, S. Mahalingam, Isolation and subgrouping of rotaviruses from buffalo calves in Sri Lanka, Res. Vet. Sci. 60 (1996) 187-189.

[34] A. Garcia, J.A. Ruiz-Santa-Quiteria, J.A. Orden, D. Cid, R. Sanz, M. Gomez-Bautista, et al., Rotavirus and concurrent infections with other enteropathogens in neonatal diarrheic dairy calves in Spain, Comp. Immunol. Microbiol. Infect. Dis. 23 (2000) 175-183. 